„Kwartalnik Filmowy” nr 112 (2020)

ISSN: 0452-9502 (Print) ISSN: 2719-2725 (Online)

https://doi.org/10.36744/kf.528

(c) Creative Commons BY-NC-ND 4.0

Malgorzata Radkiewicz

Uniwersytet Jagielloński

https://orcid.org/oooo-0001-6387-0810

\title{
„Dokumenty obrazowe" w polskiej refleksji i praktyce filmowej do roku 1927
}

\author{
Slowa kluczowe: \\ kino dokumentalne; \\ teoria filmu; \\ propaganda; \\ kino narodowe; \\ dwudziestolecie \\ międzywojenne
}

\begin{abstract}
Abstrakt
Pierwszą dekadę rozwoju polskiej kinematografii po odzyskaniu niepodległości cechują intensywne dyskusje na temat funkcji kina i jego roli w odrodzonym państwie. W refleksjach filmoznawczych podejmowanych przez intelektualistów i badaczy z różnych dziedzin (filozofia, polonistyka) oraz krytyków filmowych przewija się wątek dokumentalistycznej roli filmu oraz jego związku z rzeczywistością. Uwagom teoretycznym towarzyszą głosy o praktyce filmowej, której stawia się konkretne zadania utylitarne - obrazowanie kraju i dokumentowanie jego historii, tradycji oraz rozwoju. Prześledzenie tych wątków pozwala odtworzyć sposób myślenia o kinie jako medium dostarczającym „dokumentów obrazowych”, mogącym pełnić różnorodne funkcje: poznawczą, edukacyjną, propagandową. Rok 1927 niemal zamyka pierwszą dekadę niepodległości i zachodzące wówczas procesy, a równocześnie oznacza kres kina niemego, z jego poetyką i sposobami obrazowania oraz relacją między obrazami filmowymi a rzeczywistością.
\end{abstract}


Pierwszą dekadę rozwoju kinematografii polskiej po 1918 r. cechowały intensywne dyskusje na temat istoty kina, jego specyfiki i funkcji, zwłaszcza tych, które mogłyby korespondować z polityką odrodzonego państwa. Powracał wątek związku obrazów filmowych z rzeczywistościa, ich wartości dokumentalistycznej oraz potencjału edukacyjno-poznawczego i historycznego. Warto zwrócić uwage na fakt, że rozważaniom teoretycznym towarzyszyły bardziej pragmatyczne teksty, wskazujące rozwiązania warsztatowe i konkretne zagadnienia, które powinny zostać udokumentowane za pomocą kamery. Prześledzenie tych wątków pozwala odtworzyć sposoby myślenia o kinie i poetykach filmowej reprezentacji, przekładających się na warsztat, zainteresowania oraz postawy twórców wobec przedstawianego świata i ludzi.

Pionierskim głosem w polskiej refleksji filmowej były wydawane po francusku prace fotografa i operatora Bolesława Matuszewskiego, który już w 1898 r. pisał o dokumentach filmowych mogących stanowić nowe źródło historii. Argumentował przy tym, że ten typ „dokumentów obrazowych” będzie się rozwijał, jeśli tylko uwaga fotografów kinematograficznych przeniesie się ze scen rozrywkowych na wypadki $i$ widowiska posiadajace wartość dokumentalna ${ }^{1}$. Jego zdaniem, zamiast błahostek życia, kinematograf powinien utrwalać raczej to, co się dzieje w sferze publicznej i państwowej, zwłaszcza że zarejestrowane obrazy mogą być cennym zapisem wydarzeń dla współczesnych i przyszłych pokoleń. Matuszewski dopominał się równocześnie o nadanie właściwego znaczenia wytworom kinematograficznym, postulując, by zadbać o ich gromadzenie i archiwizację - nabrałyby one wówczas odpowiedniej rangi, zyskały autorytet i oficjalny byt², a jednocześnie stworzyłyby zasób dostępny dla osób zainteresowanych zgłębianiem przeszłości. Pionierska myśl twórcy odzwierciedlała jego fascynację obrazem filmowym, w którym widział niemal obiektywne odbicie rzeczywistości, nieulegającej zafałszowaniu ani retuszom, jak w przypadku fotografii. Ta idealistyczna wizja dokumentacyjnych możliwości kina wynikała również z faktu, że zrodziła się w pierwszych miesiącach publicznego funkcjonowania kinematografu, gdy scenki inscenizowane, oparte na pomyśle fabularnym, traktowano najczęściej jako przerywnik lub dopełnienie filmów dokumentujących codzienne realia, a nie odrębną całość.

W 1913 r. sytuacja uległa odwróceniu, o czym świadczy obserwacja Tadeusza Dąbrowskiego, że najwięcej zachwytów budzi fakt, iż kino technika swoja daje pole cudowności $i^{3}$, ukazując obrazy nieprawdopodobne w rzeczywistości. Zauważył on jednak także, że nie zawsze doceniane są inne możliwości techniki kinowej, pozwalające mimo statyczności obrazu (krajobrazu, architektury) pokazać dynamike, ruch, życie pejzażu4. Przyszłość kina widział Dąbrowski w realizmie, uznając, że kino odzwierciedlić powinno cały, bogaty zasób wspótczesnego naszego życia ${ }^{5}$, ukazywać konflikty, dramaty społeczne i bytowe; zwracał także uwagę autorom i reżyserom na konieczność pokazywania na ekranie piękna ziem dawnej Polski, uroków zamków, dworków, kościołów - a wszystko to [winno być] powiąane umiejętnie z pomoca akcji interesujacej, utrzymującej się na poziomie dzisiejszej naszej kultury literackiej' ${ }^{6}$.

Podobne wątki można odnaleźć w tekście Karola Irzykowskiego o przewrotnym tytule Śmierć kinematografu ${ }^{7}$, w którym przedstawił wizję kina jako sztuki ruchu, czerpiącej z innych dziedzin (literatury, malarstwa), lecz tylko po to, by wypracować swoje własne efekty. Irzykowski podkreślił swoistość kinowych 
przedstawień, stwierdzając, że każdy dramat kinowy zawiera kontemplacje ruchu, sceny z dokumentalną uważnością pokazujące drobne z pozoru działania, ale nad każdym takim epizodem unosi się aureola odrębnego piękna (...). Jest to liryka ruchu ${ }^{8}$. Aby osiągnąć podobną liryczność, realizatorzy starają się sięgać po szczególne tematy ruchowe, (...) wyścigi samochodu z lokomotywa, spuszczanie okrętu na wodę, (...) i naokoło nich grupuja dopiero różne historie ${ }^{9}$. W późniejszych rozważaniach Irzykowski powiązał ruch ze specyfiką kinowej widzialności, która zaspokaja ludzką potrzebę ogladania rzeczy i spraw w oderwaniu od rzeczywistości ${ }^{10}$. Zaznaczył przy tym, że kino tylko na pozór cechuje fotograficzny obiektywizm, bowiem spełnia ono raczej funkcję filtra - pokazuje się w nim optyczna strona wszechzdarzeńn ${ }^{11}$. Ta dążność do uoptycznienia świata ${ }^{12}$ sprawia, że aparat kinowy nie tylko oddaje to, co się zwykle ogląda, ale też podglada za nas wytrwale i odważnie także to, czego nie widujemy wskutek niedostępności lub niecierpliwości ${ }^{13}$.

Z perspektywy rozwoju polskiej kinematografii po 1918 r. to właśnie dokumentacyjny potencjał kina rejestrującego na bieżąco wydarzenia i obrazującego rzeczywistość okazał się szczególnie ważny. Największy nacisk położono wówczas na propagandowy aspekt realizacji, o czym świadczy tekst Mariana Stępowskiego

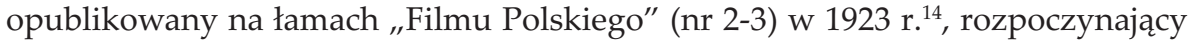
się od stwierdzenia, że rzecza chyba zgoła zbyteczna byłoby uzasadniać, że kinematograf dla celów propagandowych jest środkiem równie potężnym, jak prasa ${ }^{15}$. Pretekstem do napisania artykułu był nieudany obraz D’Elmoro - walka o skarby (reż. Jan Kucharski, 1922), który powstał przy poparciu Ministerstwa Spraw Zagranicznych i miał być biletem wizytowym odrodzonej Polski za granicą. Tymczasem, jeśli chodzi o dokumentację i popularyzację polskich realiów, przedsięwzięcie okazało się porażka, gdyż zdaniem Stępowskiego reżyser zbagatelizowat momenty propagandowe, potraktowat jako niepotrzebny balast w obrazie, a caty nacisk przenióst na fabute dramatyczna, która zagłuszyła pierwiastek propagandy ${ }^{16}$. Jak twierdzi autor: Można by oczywiście stanać na tym stanowisku, że dramat, aby byt interesujacy $i$ zdobyt petne uznanie u publiczności, musi swoja tendencje propagandystyczna dyskretnie ukrywać w opowieści filmowej, w danym jednak wypadku może być mowa nie o dyskrecji w użyciu środków, lecz o zupełnym ubóstwie pomysłowości reżysera ${ }^{17}$. Porażka filmu Kucharskiego powinna więc uświadomić realizatorom, że aby stworzyć film dobry, trzeba, aby wszystkie jego czynniki składowe złożyły się w harmonijna całośćc ${ }^{18}$.

Kwestia sprostania przez kino nie tyle zadaniom dokumentacyjnym czy propagandowym, lecz przede wszystkim wymogom artystyczno-warsztatowym, powróciła w pismach teoretycznych Stefanii Zahorskiej, która przedstawiła swoje przemyślenia na temat estetyki kina na II Zjeździe Filozoficznym w Warszawie w 1927 r., wprowadzając refleksję filmową do kręgu akademickiego. Zahorska skupiła się na zagadnieniach formalnych filmu, który uznała za sztukę czterech wymiarów, czyli konglomerat czynników plastyczno-malarskich i rytmiczno-ruchowych. Analiza wrażeń wzrokowych, obrazów, rytmu i ruchu oraz napięć między treścią i formą pozwoliła jej pokazać różnorodność możliwych realizacji kinowych, obejmujących filmy abstrakcyjne, tematyczne, realistyczne i stylizowane $^{19}$. Jak zaznaczyła, choć aparat kinowy skłania do rejestrowania najdrobniejszych szczegółów rzeczywistości, które jest w stanie uchwycić, to jednak możliwość najbardziej fantastycznych zestawień tych realistycznych czasteczek ${ }^{20}$ pozwala wyjść daleko poza granice rzeczywistości. 
Wystąpienie Matuszewskiego oraz późniejsza o trzydzieści lat wypowiedź Zahorskiej stanowiły wyznaczniki kolejnych etapów w rozwoju polskiej refleksji filmowej ${ }^{21}$, a równocześnie tworzyły ramę pojęciową i problemową dla kina polskiego lat 20. XX w. Prześledzenie głosów oraz stanowisk, które pojawiły się przed 1927 r. - czyli zjazdowym wystąpieniem Zahorskiej - w polskiej prasie oraz ówczesnych publikacjach pozwala odtworzyć sposoby myślenia o filmie epoki kina sprzed przełomu dźwiękowego. Równocześnie wraz z lekturą pism teoretycznych warto dokonać oglądu produkcji filmowych z tego okresu, w których próbowano na różne sposoby realizować cele dokumentacyjno-propagandowe, ale także warsztatowo-formalne, omawiane przez teoretyków i krytyków. Trudno doszukiwać się tu bezpośrednich związków, niemniej jednak istnieje korelacja między namysłem teoretycznym a praktycznymi realizacjami, co pokazują otwierające dekadę obrazy poświęcone wojnie polsko-bolszewickiej oraz zamykający ją Zew morza (reż. Henryk Szaro, 1927). Film ten uznaje się za najdojrzalszą produkcję polskiego kina niemego, można więc potraktować go jako symboliczną kulminację wypracowanej wówczas poetyki i sposobów obrazowania.

\section{Niepodległość w ,dokumentach obrazowych"}

Relacje i zależności między rzeczywistością odrodzonej Polski a kształtującą się kinematografią 22 i stojącymi przed nią zadaniami, zwłaszcza propagandowymi, stały się dla Stępowskiego podstawą do dokonania trójdziałowej, tematycznej kategoryzacji dokonań kinematograficznych. Do pierwszej grupy zaliczył on produkcje poświęcone dokumentowaniu konsekwencji I wojny światowej, aby zdobyć przychylność obcych państw dla Polski zrujnowanej i głodujacej23. W grupie drugiej umieścił filmy ukierunkowane na propagandę antybolszewicka, powstałe jeszcze w trakcie albo tuż po zakończeniu konfliktu ze Związkiem Radzieckim w 1920 r., takie jak m.in.: Bohaterstwo polskiego skauta (reż. Ryszard Bolesławski, 1920), Cud nad Wisła (reż. Ryszard Bolesławski, 1921), Tajemnica medalionu (reż. Edward Puchalski, 1922). Wyznacznikiem trzeciego typu filmów były już jednak inne momenty propagandowe, które Stępowski wiązał z teraźniejszością i sprawami bieżącymi. Jak stwierdził: Musimy głosić całemu światu, że Polska jako „młode” państwo suwerenne posiada niezmierzone skarby i sity żywotne (... $)^{24}$.

Gdyby na tę typologię spojrzeć z perspektywy Matuszewskiego, to oprócz funkcji propagandowej należałoby zaakcentować rolę poznawczo-edukacyjną powstających filmów, oferujących bezpośrednia wizjęe $e^{25}$ nawet jeśli kinematograf nie ukazuje, być może, historii w jej petnym kształcie ${ }^{26}$. Idea „,bezpośredniości wizji” z pewnością towarzyszyła powstawaniu filmu Dla Ciebie, Polsko wyreżyserowanego przez Antoniego Bednarczyka w 1920 r., a także późniejszego o rok Cudu nad Wistą ${ }^{27}$. W obu realizacjach sceny fabularne splatają się z ujęciami opartymi na bezpośrednich relacjach i doświadczeniach z pola walki oraz z - zamieszczonymi w finale - fragmentami kronik dokumentujących wydarzenia państwowe z udziałem władz i żołnierzy.

Akcja filmu Dla Ciebie, Polsko toczyła się na Wileńszczyźnie, dokąd na początku 1919 r. wkroczyła Armia Czerwona dokonująca spustoszeń i zbrodni. Realizacja filmu w czasie, gdy wciąż toczyły się walki frontowe, sprawiła, że 
poszczególne sceny i epizody musiały wchodzić w swoistą dokumentacyjno-komentatorską relację z aktualnymi zdarzeniami. Spowodowało to, że osobą odpowiedzialną za scenariusz uczyniono Mariana Józefowicza, który jako zawodowy wojskowy znał wojenne realia i potrafił je przełożyć na opowieść fabularną zbudowaną wokół melodramatycznej historii zakochanej chłopskiej pary. Wątek Franka, wcielonego do wojska, oraz Hanki, gotowej wzorem wielu legionistek ${ }^{28}$ ściąć włosy i nałożyć męski mundur, by podążyć jego śladem, został wpleciony w relację z walk oraz grabieżczych napadów bolszewików. O należytą inscenizację scen batalistycznych, fotografowanych przez Stefana Sabela, zadbała wytwórnia Polfilma oraz Centralny Urząd Filmowy Wojska Polskiego, zapewniając statystów i sprzęt wojskowy. Fabularną produkcję Dla Ciebie, Polsko, tak mocno osadzoną w ówczesnych realiach, można potraktować jako odpowiedź na ograniczenia w pracy dokumentacyjnej z kamera, o których pisał Matuszewski. Z jednej strony przywiązywał on ogromną wagę do gromadzenia dokumentalnych obrazów wydarzeń, by mogli je później oglądać ci, którzy nie byli ich świadkami, z drugiej jednak zdawał sobie sprawę, że fakt historyczny nie zdarza się tam, gdzie się go oczekuje. Historia nie składa sie jedynie z uroczystości przewidzianych, uprzednio zorganizowanych $i$ gotowych do sfotografowania ${ }^{29}$. Dlatego autor zachęcał, by starać się uchwycić jak najwięcej z filmowanej rzeczywistości, zwłaszcza że ukazane jasno przez kinematografię skutki oświetla jaskrawo ukryte w ich cieniu przyczyny ${ }^{30}$.

Realizatorzy Cudu nad Wista byli w stanie oprzeć scenariusz na wiedzy historycznej o zakończonym już konflikcie ze świadomością że istnieje jakiś poczatek wydarzeń, pewne ruchy wstępne, fakty nieoczekiwane, zdolne ujść czujności obiektywu... podobnie zreszta jak uwadze obserwatoróz ${ }^{31}$. Mogli więc także włączyć do rozbudowanej, dwuczęściowej (dwuseryjnej) opowieści nie tylko uporządkowane epizody, ale także ich interpretację. Daje się to zauważyć w sekwencji ukazującej żołnierzy prowadzonych do walki w przełomowej bitwie przez księdza Ignacego Skorupkę, który jawi się jako symboliczny przywódca i nieugięty bohater, na stałe wpisany w ikonografię bitwy warszawskiej. Przeciwwagą dla obrazów walczących żołnierzy są sceny w szpitalu polowym ukazujące zaplecze frontowe i rozgrywające się tam dramaty. Podobnie jak w filmie Dla Ciebie, Polsko, także w zakończeniu Cudu nad Wisła pojawiają się fragmenty dokumentalne z udziałem Józefa Piłsudskiego, już nie dotyczące defilady po zdobyciu Wilna, ale uroczystości odebrania przez niego buławy marszałkowskiej 14 listopada $1920 \mathrm{r}$.

O sile oddziaływania obu tych obrazów i ich znaczeniu jako źródła historii związanego z wojną polsko-bolszewicką świadczy anons, który - jako część reklamy Cudu nad Wisła - pojawił się w „Kurierze Porannym”. Oznajmiał on: Każdy, w czyjej piersi bije serce Polaka, miłujacego swoją Ojczyznę. Każdy, kto osobiście brał udziat $w$ bohaterskich walkach roku ubiegłego przeciw czerwonej armii i własna piersia obronit Ojczyzne przed zalewem nieprzyjacielskim. Każdy, kto dzięki niezłomnemu bohaterstwu naszych dzielnych zuchów, uchronił swe mienie od grabieży, swe ognisko rodzinne od pohańbienia. Każdy niech zobaczy wielki obraz w 2-ch seriach p.t.: „Cud nad Wista"32.

O innym aspekcie pracy nad dokumentem filmowym można mówić w przypadku reportażu Wojna polsko-rosyjska powstałego w sierpniu 1920 r. w okolicach Nasielska w celu ukazania działań wojskowych oraz wydarzeń rozgrywających się poza linią frontu. Dociekliwość, z jaką kamera podąża za oddziałami przeprawiającymi się przez rzekę, transportującymi amunicję lub odpoczywają- 
cymi przed walka, można tłumaczyć tym, że działa ona niczym osobnik niedys$k_{r e t n y}{ }^{33}$. Zdaniem Matuszewskiego udział aparatu kinematograficznego w wydarzeniach polega głównie na czekaniu i obserwacji, bowiem czatując na jakaśs sposobność, odgadnie on często instynktem miejsce, gdzie nastapia fakty, które stana się przyczynami historycznymi. (...) tatwo go sobie wyobrazić w czasie wojny, wycelowujacego swój obiektyw z tego samego szańca co karabiny i fotografujacego jakiś przynajmniej fragment bitwy ${ }^{34}$. Spojrzenie na materiały wykorzystane w reportażu wojennym jako na efekt tak pojmowanej „niedyskrecji” pozwala dostrzec sam proces filmowania wybory punktów widzenia, selekcję ujęć i epizodów składających się na kolejne sceny. Rodzi się pytanie: co i dlaczego zyskało swoją reprezentację (obóz jeniecki, kuchnia polowa, dystrybucja ulotek propagandowych, a także drastyczne skutki walk - okopy, ostrzelane pola, zburzony most), co zaś pozostało poza ramą kadru?

Kronikarskie lub reportażowe zapisy przebiegu wojny polsko-bolszewickiej pojawiały się na ekranach obok jej fabularnych wizji. W ten sposób wytwarzało się zbiorowe imaginarium, typowe dla kina, w którym - jak twierdzi Irzykowski - powiększa się optyczna powierzchnia świata ${ }^{35}$. Chęć powiększania optycznej sfery oglądu zdarzeń stanowi uzasadnienie dla zabiegu połączenia form fabularnych i dokumentalnych w filmach Dla Ciebie, Polsko oraz Cud nad Wista, angażujących widzów jako świadków dramatycznych losów postaci fikcyjnych oraz bohaterów autentycznych. O podobnym zjawisku pisze Teresa Rutkowska w odniesieniu do filmów z lat 20. dotyczących I wojny światowej, zwracając uwagę, że utwory literackie, poświęcone traumatycznym wydarzeniom, zostały szybko zekranizowane, dzięki czemu zyskały znacznie szerszy zasięg oddziaływania. Adaptacje przybliżały widzom fakty historyczne i doświadczenia żołnierzy w formie fabularnej, w efekcie czego obrazy filmowe - po raz pierwszy na taka skale i na użytek tak wielu odbiorców - wycisnęty najmocniejsze piętno na zbiorowej pamięci kolejnych pokoleń o wojnie ${ }^{36}$.

\section{Pierwszy polski film morski}

Andrzej Włast w felietonie o Niewolnicy zmysłów (reż. Jan Kucharski, Stanisław Szebego, 1924) narzekał na łamach „Ekranu i Sceny” na nieudany scenariusz oraz sztampową grę wykonawców, których twórcy nie próbowali nawet wyprowadzić z deptaka szablonu warszawskiego ${ }^{37}$. Krytycznie ocenił też nieporadność w przedstawianiu lokalnego kolorytu i miejskich przestrzeni, stwierdzając, że przecież mamy dość tła czysto polskiego, aby stworzyć nasz własny motyw w kinematografie ${ }^{38}$. Jako obszary poszukiwań motywu polskości $i^{39}$ autor sugerował folklor, arcydzieła rodzimej literatury lub historię. Wydaje się, że realizatorzy filmu Zew morza podążyli za radą Własta, łącząc dwa porządki: fantastyczny i realistyczny, by opowiedzieć o legendach i podaniach związanych z Bałtykiem. Imponujące przedsięwzięcie wytwórni Leo-Film, kierowanej przez Marię Hirszbein, prasa natychmiast obwołała pierwszym polskim filmem morskim, skwapliwie donosząc o kolejnych etapach jego powstawania.

Autorowi pierwowzoru literackiego oraz scenariusza, Stefanowi Kiedrzyńskiemu, zależało zwłaszcza na edukacyjno-poznawczych oraz patriotycznych walorach filmu. Zakładał bowiem, że świadomość posiadania morza w szerokich sferach naszego narodu jest tak świeża, a nawet niezbyt jasna, że uważałem za swój obowiązek (...) poświęcić swa prace przypomnieniu szerokim masom naszych widzów kinematograficz- 
nych, że bądź co badź jesteśmy narodem morskim, a posiadanie okna na Europę jest czymś tak ważnym i wielkim, że należy o tym pamiętać w każdej godzinie życia ${ }^{40}$. Powaga scenarzysty w podejściu do podjętego tematu przełożyła się na dokumentalny charakter sekwencji współczesnych, realizowanych w autentycznych miejscach w porcie w Gdyni, Gdańsku oraz w Pucku, z udziałem członków dowództwa oraz żołnierzy Polskiej Marynarki Wojennej. Melodramatyczna fabuła stała się okazją do ukazania dumy polskiej floty, zwłaszcza że część zdjęć kręcono na morzu, na autentycznych torpedowcach oraz żaglowcu należącym do Szkoły Morskiej w Tczewie. W filmie wykorzystano również hydroplan Morskiego Dywizjonu Lotniczego w Pucku, co dodatkowo zwiększało atrakcyjność ujęć filmowych.

Czuwający nad realizacją Henryk Szaro przyznał w wywiadzie, że w naturalnych plenerach zyskał nowe możliwości twórcze: W filmie morskim, nieskrępowany brakiem atelier i odpowiednio wyszkolonych statystów, reżyser łatwiej może rozwinać swa inwencje i lepiej opracować każdy szczegót $t^{41}$. W efekcie nowatorskich rozwiązań i pracy całej ekipy Zew morza sprostał zadaniom poznawczym oraz społeczno-wychowawczym, jakie wiązał z kinem Jan Stanisław Bystroń. Twierdził on, że ekran, bez względu na to czy daje nam obraz przyrody, zabawna farse, demonstracje naukowe czy dramat psychologiczny, podaje pewna treść i wzbogaca w ten sposób nasze pojęcie o świe$\mathrm{cie}^{42}$. Dokumentalny charakter sekwencji realizowanych nad morzem z pewnością zaspokoił ciekawość poznawczą widzów, których Bystroń uznał za przedstawicieli nowego typu ludzi stworzonego przez kinoteatr. Z obserwacji badacza wynika, że pod wpływem oglądanych filmów widz kinematografu staje się zewnętrznym kosmopolita, urbanizuje się, zaczyna się lepiej czuć w dalekim, choćby i obcym mieście aniżeli w pobliskiej wsi, nieogarniętej jeszcze powszechnym prądem niwelacji światowej ${ }^{43}$.

Za konsekwencję założenia Bystronia, głoszącego, że odbiorca filmowy staje się przed ekranem turysta szerokiego świata ${ }^{44}$, dla którego żadne środowisko nie jest obce, można uznać drobiazgowość, z jaką prasa relacjonowała, jak powstaje Zew morza, dostarczając szczegółów z planu filmowego. W raporcie dla „Kina dla Wszystkich" skwapliwie odnotowano, że w Pucku pojawienie się samochodów z ekipą i artystami wzbudziło prawdziwą sensację: Zwartym szeregiem obstapiono operatora $p$. Steinwurzla, podziwiając potyskujące w słońcu aparaty i przyrzady. (...) Pania Malicka natychmiast obstapity tłumy wielbicielit5. Na planie filmowym w Gdyni zauważono natomiast, że reż. Henryk Szaro z iście amerykańskim rozmachem prowadzit sceny pościgu, zaprzagłszy do pracy torpedowiec, kuter, holownik i hydroplan ${ }^{46}$, a operator Steinwurzel wykazuje się niezwykłą sprawnością warsztatowa, obsługując nowy francuski aparat o niebywałej podobno precyzji ${ }^{47}$.

O umiejętnościach ekipy pracującej nad filmem Zew morza napisano raz jeszcze po premierze, podsumowując, że reżyser Szaro okazuje się tu skończonym artysta w swoim fachu, umiejacym stosować niespodziewane pointy, a w pogoni za nowymi drogami - te drogi istotnie odnajdywaćt8. Według "ABC" o sukcesie filmu zdecydowało połączenie sprawnie poprowadzonej opowieści z doskonałymi zdjęciami, w efekcie czego pokazano nam film naprawde morski i naprawde interesujacy ${ }^{49}$. Jednocześnie zwrócono uwagę na patriotyczny wymiar filmu Zew morza, podkreślając, że już sam tytuł pięknie brzmi w państwie, które od niespełna roku rozpoczęło na serio budować flote morska i rozbudowywać własny port ${ }^{50}$. Zaznaczono przy tym, że nie jest to nachalna edukacyjność, a że element propagandy przewija się równolegle z ciekawa akcja, że twórcy tego filmu zadbali o precyzyjne wykończenie technicznej strony obrazu, dając 
czyste, jasne i plastyczne zdjęcia, więc widz osiaga wiele satysfakcji ${ }^{51}$. Zew morza, dokumentujący z pietyzmem morską tradycję niepodległego państwa, wydaje się przynależeć do tej grupy filmów, o których Matuszewski pisał, że zapisane na taśmie stanowią nie tylko dokument historyczny, lecz także cząstkę historii ${ }^{52}$.

Te różnorodne głosy teoretyczne i praktyki realizacyjne pokazuja, że kwestia „dokumentów obrazowych", jak nazywał je Matuszewski, ich formy i funkcji, była jednym z najważniejszych wątków w toczącej się dyskusji o istocie kina i jego narodowym charakterze. Wprawdzie trudno zakładać, że producenci, reżyserzy i scenarzyści śledzili teoretycznofilmowe rozważania i podążali za zawartymi w nich przemyśleniami, z pewnością jednak stykali się z recenzjami filmów, pisanymi w dużej mierze przez autorów pochodzących z tego samego grona, nie unikających teoretyzowania choćby w lekkiej, felietonowej formie. Zwłaszcza że sprzyjała ona polemikom oraz często prowokacyjnym tezom na temat poetyki filmu, jego wartości historycznej oraz sposobów oddziaływania na widzów.

Pochodzące z lat 1898-1927 refleksje polskich autorów na temat „dokumentów obrazowych" i dokumentujących aspektów kina wpisują się w tradycję, którą Dudley Andrew określa mianem wielkiego okresu teorii formy ${ }^{53}$ przypadającego na pierwsze trzy dekady XX w. Prowadzone wówczas dyskusje dotyczyły pytania o to, czy kino jest sztuka, jak przebiega jego relacja z rzeczywistością i jak dokonuje się w nim przemiana surowego materiału w znaczącą wypowiedź. Na tak sformułowane kwestie odpowiadała Stefania Zahorska, uznając, że film jest pierwszą sztuka, która pozwala ukazać rzeczywistość nie jako stężały przekrój, lecz jako stawanie się ${ }^{54}$. Krytyczka nie proponowała, by określić jednoznacznie stosunek kina do rzeczywistości jako uważną rejestrację lub kreacyjne przetwarzanie, lecz sugerowała, że najbliżej natury filmu jest droga, która można by nazwać pótrealizmem, czy też ponadrealizmem. W konsekwencji filmy pozwalałyby wyrazić obrazowo nasze wyczucie energii i dynamiki życia ${ }^{55}$, tak w formie fabularnej, jak i dokumentalnej. Wydaje się, że podobny efekt próbowali osiągnąć twórcy polskich filmów pierwszej dekady niepodległości, usiłując pogodzić dokumentalistyczne obrazowanie realiów z atrakcyjnością widowiska będącego nośnikiem treści edukacyjnych i ideowych.

${ }^{1}$ B. Matuszewski, Nowe źródło historii, tłum. B. Michałek, w: Polska myśl filmowa. Antologia tekstów z lat 1898-1939, wybór i oprac. J. Bocheńska, Ossolineum, Wrocław 1975, s. 13.

2 Tamże, s. 16.

${ }^{3}$ T. Dąbrowski, O sztuce kinoteatru, w: Polska myśl filmowa... dz. cyt., s. 47.

${ }^{4}$ Tamże.

5 Tamże, s. 48.

${ }^{6}$ Tamże.

${ }^{7}$ K. Irzykowski, Śmierć kinematografu?, w: Polska myśl filmowa... dz. cyt., s. 70-76.

8 Tamże, s. 74 .

${ }^{9}$ Tamże.

${ }^{10}$ K. Irzykowski, X Muza. Zagadnienia estetyczne kina, Wydawnictwa Artystyczne i Filmowe, Warszawa 1977, s. 54.

11 Tamże, s. 55.
12 Tamże, s. 56.

${ }^{13}$ Tamże.

14 Zob. M. Stępowski, Pierwiastki propagandy państwowej w filmach polskich. Z powodu obrazu pt. "D'Elmoro-walka o skarby", w: Polski film fabularny 1918-1939. Recenzje, wstęp, wybór i oprac. L. Gierszewska, Księgarnia Akademicka, Kraków 2012, s. 43-48.

15 Tamże, s. 43.

16 Tamże, s. 45.

17 Tamże.

18 Tamże.

${ }^{19}$ S. Zahorska, Zagadnienia formalne filmu, w: Polska myśl filmowa... dz. cyt., s. 154.

${ }^{20}$ Tamże.

${ }^{21}$ Jadwiga Bocheńska dokonuje podziału polskiej refleksji międzywojennej na trzy okresy: pierwszy 1898-1917, drugi 1918-1928, 
trzeci 1929-1939. Zob. J. Bocheńska, Polska myśl filmowa do roku 1939, Ossolineum, Wrocław 1974.

${ }^{22}$ Zob. M. Hendrykowska, Film w budowaniu polskiej tożsamości. Pierwsze lata niepodległości 1919-1924, w: 1918 - kino polskie wobec odzyskania niepodległości, red. M. Guzek, P. Zwierzchowski, Wydawnictwo Uniwersytetu Kazimierza Wielkiego, Bydgoszcz 2020, s. 9-25.

${ }^{23}$ M. Stępowski, Pierwiastki propagandy państwowej... dz. cyt., s. 39.

24 Tamże.

${ }^{25}$ B. Matuszewski, dz. cyt., s. 13.

${ }^{26}$ Tamże, s. 15.

27 Zob. M. Radkiewicz, Z kamera na pierwszej linii, w: Fotorelacje. Wojna 1920 (katalog wystawy), Muzeum Narodowe, Warszawa 2020, s. $108-117$.

${ }^{28}$ Zob. M. Radkiewicz, Kobiety czasu Wielkiej Wojny w fotografii, ,Herito: Dziedzictwo, Kultura, Współczesność" 2014, nr 16, s. 92-103.

${ }^{29}$ B. Matuszewski, dz. cyt., s. 14.

${ }^{30}$ Tamże.

${ }^{31}$ Tamże.

32 [b. a.], [brak tytułu], „Kurier Poranny” 1921, nr 72 (cyt. wg: http://www.repozytorium.fn.org.pl/?q=pl/node/5216 /dostęp: 7.12.2020/).

${ }^{33}$ B. Matuszewski, dz. cyt., s. 14

${ }^{34}$ Tamże.

${ }^{35}$ K. Irzykowski, X Muza... dz. cyt., s. 56.

${ }^{36}$ T. Rutkowska, Szaleńcy $i$ żołnierze nieznani, „Kwartalnik Filmowy” 2015, nr 92, s. 7.

37 A. Włast, Dziesiata Muza (Impresje). Felietony filmowe z lat 1923-1924, red. W. Świdziński, Instytut Sztuki Polskiej Akademii Nauk, Warszawa 2017, s. 130.

38 Tamże.

${ }^{39}$ Tamże.
${ }^{40}$ [b. a.], [brak tytułu], "Comoedia” 1927, nr 32-33 (cyt. wg: http://www.repozytorium.fn.org.pl/?q=pl/node/9992 /dostęp: 7.12.2020/)

41 [b. a.], Jak kręce film? "ABC" u reżysera Szaro, „ABC" 1927, nr 279 (cyt. wg: http://www.repozytorium.fn.org.pl/?q=pl/node/9992 /dostęp: 7.12.2020/).

42 J. S. Bystroń, Socjologia kina, w: Polska myśl filmowa... dz. cyt., s. 98-99.

43 Tamże, s. 100.

${ }^{44}$ Tamże.

${ }^{45}$ M. B-ski, Jak się tworzy pierwszy polski film morski?, „Kino Dla Wszystkich” 1927, nr 47 (cyt. wg: http://www.repozytorium.fn.org.pl/?q=pl/node/9992 /dostęp: 7.12.2020/).

${ }^{46}$ Tamże.

${ }^{47}$ L. B., [brak tytułu], "Kurier Warszawski” 1927, nr 228 (cyt. wg: http://www.repozytorium.fn.org.pl/?q=pl/node/9992 /dostęp: 7.12.2020/)

${ }^{48}$ [b. a.], [brak tytułu], "Kino dla Wszystkich” 1927, nr 52 (cyt. wg: http://www.repozytorium.fn.org.pl/?q=pl/node/9992 /dostęp: 7.12.2020/).

${ }^{49}$ [b. a.], [brak tytułu], „ABC” 1927, nr 286 (cyt. wg: http://www.repozytorium.fn.org.pl/?q=pl/node/9992 /dostęp: 7.12.2020/).

${ }^{50}$ Tamże.

51 [b. a.], Zew morza, "Ilustrowany Tygodnik Polski" 1927, nr 37 (cyt. wg: http://www.repozytorium.fn.org.pl/?q=pl/node/9992 /dostęp: 7.12.2020/).

52 B. Matuszewski, dz. cyt., s. 13.

${ }^{53}$ D. J. Andrew, Główne teorie filmu. Wprowadzenie, tłum. A. Kołodyński, PWSFTviT, Łódź 1995, s. 27.

${ }^{54}$ S. Zahorska, dz. cyt., s. 154.

55 Tamże. Malgorzata
Radkiewicz
Profesor dr hab., filmoznawczyni; pracuje w Instytucie Sztuk Audiowizualnych Uniwersytetu Jagiellońskiego, gdzie kieruje Katedrą Historii Filmu Polskiego. Zajmuje się problematyką tożsamości kulturowej oraz twórczością kobiet w kinie, fotografii i sztuce współczesnej. Wyrazem jej zainteresowań są publikacje: W poszukizæaniu sposobu ekspresji. O filmach Fane Campion i Sally Potter (2001), Władczynie spojrzenia. Teoria filmu a praktyka rezyserek i artystek (2010). Ponadto autorka książek: Derek Farman. Portret indywidualisty (2003), Mtode wilki polskiego kina. Kategoria gender a debiuty lat 9o. (2006) oraz Oblicza kina queer (2014). W latach 
2015-2018 koordynatorka projektu badawczego Narodowego Centrum Nauki: „Pionierki z kamerą. Kobiety w kinie i fotografii w Galicji 1896-1945”, podsumowanego w licznych artykułach. Jako stypendystka Ministra Kultury i Dziedzictwa Narodowego w 2015 r. prowadziła badania opublikowane w monografii: Modernistki o kinie. Kobiety w polskiej krytyce i publicystyce filmowej 1918-1939 (2016). Członkini Polskiego Towarzystwa Kulturoznawczego oraz Polskiego Towarzystwa Badań nad Filmem i Mediami.

\section{Bibliografia}

[b. a.] (1921). [brak tytułu]. Kurier Poranny, (72). http://www.repozytorium.fn.org.pl/?$\mathrm{q}=\mathrm{pl} /$ node $/ 5216$

[b. a.] (1927). Jak kręcę film? „ABC” u reżysera Szaro. $A B C$, (279). http://www.repozytorium.fn.org.pl/?q=pl/node/9992

[b. a.] (1927). [brak tytułu]. Comoedia, (32-33). http://www.repozytorium.fn.org.pl/?$\mathrm{q}=\mathrm{pl} /$ node $/ 9992$

[b. a.] (1927). [brak tytułu]. Kino dla Wszystkich, (52). http://www.repozytorium.fn.org.pl/?$\mathrm{q}=\mathrm{pl} /$ node $/ 9992$

[b. a.] (1927). [brak tytułu]. $A B C,(286)$. http://www.repozytorium.fn.org.pl/?q=pl/node/9992

[b. a.] (1927). Zew morza. Ilustrowany Tygodnik Polski, (37). http://www.repozytorium.fn.org.pl/?q=pl/node/9992

Andrew, D. J. (1995). Gtówne teorie filmu. Wprowadzenie (tum. A. Kołodyński). Łódź: PWSFTviT (Publikacja oryginału: 1976).

Bocheńska, J. (1974). Polska myśl filmowa do roku 1939. Wrocław: Ossolineum.

B-ski, M. (1927). Jak się tworzy pierwszy polski film morski?. Kino Dla Wszystkich, (47). http://www.repozytorium.fn.org.pl/?q=pl/node/9992

Bystroń, J. S. (1975). Socjologia kina. W: J. Bocheńska (red.), Polska myśl filmowa. Antologia tekstów z lat 1898-1939. Wrocław: Ossolineum.

Dąbrowski, T. (1975). O sztuce kinoteatru. W: J. Bocheńska (red.), Polska myśl filmowa. Antologia tekstów z lat 1898-1939. Wrocław: Ossolineum.

Helman, A. (1992). Co to jest kino?. Kraków: Uniwersytet Jagielloński (Skrypty uczelniane nr 670).

Hendrykowska, M. (2020). Film w budowaniu polskiej tożsamości. Pierwsze lata niepodległości 1919-1924. W: M. Guzek, P. Zwierzchowski (red.), 1918 - kino polskie wobec odzyskania niepodległości. Bydgoszcz: Wydawnictwo Uniwersytetu Kazimierza Wielkiego.

Irzykowski, K. (1975). Śmierć kinematografu?. W: J. Bocheńska (red.), Polska myśl filmowa. Antologia tekstów z lat 1898-1939. Wrocław: Ossolineum.

Irzykowski, K. (1977). X Muza. Zagadnienia estetyczne kina. Warszawa: Wydawnictwa Artystyczne i Filmowe.

L. B. (1927). [brak tytułu]. Kurier Warszawski, (228). http://www.repozytorium.fn.org.pl/?q=pl/node/9992 
Matuszewski, B. (1975). Nowe źródło historii (tłum. B. Michałek). W: J. Bocheńska (red.), Polska myśl filmowa. Antologia tekstów z lat 1898-1939. Wrocław: Ossolineum. Radkiewicz, M. (2014). Kobiety czasu Wielkiej Wojny w fotografii. Herito: Dziedzictwo, Kultura, Wspótczesność, (16), ss. 92-103.

Radkiewicz, M. (2020). Z kamerą na pierwszej linii. W: Fotorelacje. Wojna 1920 (katalog wystawy). Warszawa: Muzeum Narodowe.

Rutkowska, T. (2015). Szaleńcy i żołnierze nieznani. Kæ̋artalnik Filmowy, (92), ss. 6-21.

Stępowski, M. (2012). Pierwiastki propagandy państwowej w filmach polskich. Z powodu obrazu pt. „D’Elmoro - walka o skarby”. W: L. Gierszewska (red.), Polski film fabularny 1918-1939. Recenzje. Kraków: Księgarnia Akademicka.

Wlast, A. (2017). Dziesiata Muza (Impresje). Felietony filmowe z lat 1923-1924 (red. W. Świdziński). Warszawa: Instytut Sztuki Polskiej Akademii Nauk.

Zahorska, S. (1975). Zagadnienia formalne filmu. W: J. Bocheńska (red.), Polska myśl filmowa. Antologia tekstów z lat 1898-1939. Wrocław: Ossolineum.

\author{
Keywords: \\ documentary; \\ film theory; \\ propaganda; \\ national cinema; \\ interwar period
}

\begin{abstract}
Małgorzata Radkiewicz

"Visual documents" in Writings on Cinema and in Filmmaking in Poland Before 1927
\end{abstract}

The first decade of the Polish cinema following the country's regaining of independence in 1918 is marked by intensive discussions about the roles and functions of the national film industry. Many academics (from Polish studies, philosophy) and film critics addressed the issue of documentary filmmaking and the relation between the film image and reality. Theoretical reflections were accompanied by practical comments and pieces of advice on how to use documentaries for the purposes of political propaganda, education, popularization of Polish history, heritage and present development. Tracing these motifs in the writings on films of that time makes it possible to reconstruct a way of thinking about the medium as providing "visual documents" performing cognitive, educational, or propaganda functions. The year 1927 seems to be significant for two reasons; as the end of the decade of independent Poland and as the time when the sound era of cinema was about to start, and the silent film poetics of representation was going to change. 